\title{
From the editor: International business policy: What it is, and what it is not
}

\author{
Jeremy Clegg
}

Leeds University Business School, University of Leeds, Maurice Keyworth Building, Leeds LS2 9JT, UK

\section{Correspondence:}

J Clegg, Leeds University Business School, University of Leeds, Maurice Keyworth Building, Leeds LS2 9JT, UK.

Tel: +44 (0) 113343 4512;

e-mail: ljc@lubs.leeds.ac.uk

\begin{abstract}
Institutions shape behavior, but it is policy that changes behavior. When public policy is applied, governments effect institutional change. This editorial is about the distinction between policies and institutions and the research opportunities it provides for authors. Institutional theory is known for its weak ability to provide a predictive model of firm behavior in a comparative static setting. Theoretically and empirically isolating the causal mechanisms involved in institutional change is thus a natural challenge that comes to a head in international business policy research. Adding to this, policy responses are not slavish: firms actively engage in institutional work and corporate political lobbying in order to change formal institutions and affect future policy. To contribute to these research areas, scholars need to design-in policy questions from the outset of their research projects and make certain to include the two essential elements of international business policy: intent by policy makers and suitable institutions to implement change in firm behavior. Analyses of policy antecedents, firm influence upon policy, policy implementation, policy uptake, and impact are all fruitful areas of enquiry. Meeting these requirements will ensure that a study passes the relevance-to-policy test.
\end{abstract}

Journal of International Business Policy (2019) 2, | | |-1 |8.

https://doi.org/10.1057/s422 I4-019-00025-w

Keywords: international business; policy; institutions

\section{INTRODUCTION}

It was inescapable to me and my track co-chair, Miguel Matos Torres, responsible for the brand-new International Business Policy Track at the 2017 Academy of International Business annual meeting in Dubai, that there was a problem. Despite our best efforts, almost all of the submissions to the track concerned institutional theory and institutions. If policy was mentioned at all, it was as an afterthought, right at the end of the paper, simply to give a veneer of relevance. Mostly, however, the papers did not even attempt this. We accepted as many papers as we could - those we felt had the potential for a policy dimension. At this point began - in earnest - the mission to articulate how international business policy is necessarily distinct from institutional theory simply transposed into an international setting.

The great contribution of institutional theory is to demonstrate that economic behavior, and therefore business behavior, cannot be fully understood without recourse to the social construction of 
the principles that regulate human decision making (North, 1991). "Rational economic man" has no need of institutions other than a complete set of markets. This is the self-interested decision-making individual human mind with unbounded processing power born of neoclassical economics (Edgeworth, 1881). The representative individual makes decisions based on fixed preferences, with perfect information. Rationality such as this is an explicit or implicit assumption in much of the research on decision making by firms. While it explains a large proportion of observed behavior, its predictive power wanes when strong effects originate outside of markets, such as we might observe when comparing different economies.

One reason why institutional theory has become so popular is that people believe it can simply be layered on top of a standard model of decisionmaking. However, this leaves a theoretical deficit within our framework: what happens when realworld institutions change and what model of decision-making truly describes firm behavior in such a setting? We need to understand the institutional change process and we need an accurate model of how firms make decisions if we are to be able to predict how they behave when acted upon by policy. This is one of the main reasons why institutional theory is relatively poor at making predictions in an international context.

There is another problem: how do we scale up principles of decision making from the individual level to the level of the firm, and from the firm level to the level of the country? If individuals maximize their own utility, how does this square with the social choice that should be fundamental to public decision making and public policy? Institutionalism - the movement towards incorporating institutions into decision-making models - has yielded theory and a body of literature to tell us what the influences are, but falls short of being able to make predictions with any precision. Thus, the construction of a theoretical bridge backwards from desired outcomes through decision making to international business policy is very much a work in progress.

In asking these questions, we can see more clearly the potential for international business policy research to rattle the foundations of international business theory, and potentially beyond. International business policy research undoubtedly offers a great opportunity for applied research of value to society but, at the same time, it offers at least as great an opportunity for theoretical innovation.
Rather than setting out a complete set of "do's and don'ts" for authors, this editorial must necessarily be provocative and something of a research agenda.

\section{INSTITUTIONS AND POLICY IN THE INTERNATIONAL BUSINESS DOMAIN}

I will not rehearse here the literature on institutions that has launched a thousand (surely more) international business research papers. To characterize, or rather to caricature, this now extensive literature we could say that a typical research design would be to look at comparative (static) institutions between economies, and from this infer the impact upon international business decisions. While at first blush this appears to be relevant to policy - and it may have the potential to be - it is not necessarily so, and if there is no policy dimension to the research - as opposed to comparative institutional analysis - then any such study will fail the relevance-to-policy test.

There are two common meanings in English of the word "Institution". It may be a "large organization founded for a particular purpose", more specifically, "an official organization with an important role within a country", for example, the central bank of an economy. Or it may be "an established law or custom" (Oxford English Dictionary, 2004). Thus, an institution might form part of the official infrastructure of governance, e.g., the courts, legislatures, and bureaucracies of a state. Alternatively, the same term might describe the constitution, laws, and regulations which are communicated, implemented, and enforced via this infrastructure. It is this second meaning - of strictures and incentives - that is intended within institutional theory. If we take the Northian approach (North, 1990) of constraints and rules, then clearly only those constraints and rules that are amendable to change through an act of public policy - originating with the government or its agencies - can qualify as relevant to international business policy research.

While institutional theory covers both formal and informal institutions, for the Journal of International Business Policy's (JIBP) purposes it is first and foremost the formal, public, or official, domain that applies. Informal institutions are socially constructed and shared rules, i.e., regulations or principles governing conduct within a defined area of activity. They comprise a list, the length of which says more than anything else about their importance for human behavior: attitudes, values, 
traditions, customs, norms, taboos, and codes of conduct, to name but a very few. They are communicated, implemented, and enforced via social infrastructures. Although generally considered to be beyond government control, informal institutions may have an impact on the implementation of government policy, and they may even be the subject of policy in some instances, thus making them at least indirectly relevant to international business policy.

Policy is a course or principle of action adopted or proposed by an organization or individual (Oxford English Dictionary, 2004). By international business policy we mean a change intentionally instigated by government to have an action upon the decision making and behavior of firms within the international business domain (Lundan, 2018). Although institutional research is known for its weak ability to provide a predictive model of behavior, it is the burden upon policy research to do precisely this - to analyze and predict the effect of government policy upon the behavior of firms. Within the sphere of international business, this means a change in the behavior of firms that have some form of international operations. In order to make progress in international business policy research, we need to identify the levers of policy action upon firms.

\section{POLICY AS INSTITUTIONAL CHANGE}

Within the current way of thinking, institutions shape decision making by individuals and, by extension, by firms. The central message of this editorial is that international business research on how institutions shape decision making by firms is not sufficient to qualify as relevant to JIBP. To qualify as policy, we need intent by policy makers and suitable institutions to implement change. First, there must be institutional change instigated by government, its agents, or other official bodies, including international bodies mandated to determine policy. In this context, it may be relevant to investigate the antecedents of the policy-making, particularly influences upon government in making changes, such as corporate political action. However, the point is that at some juncture official agency must be present to bear the name of policy. It is perfectly possible that other organizations or associations within society may have direct policylike effects, such as trade associations. However, research on these other aspects would lie more in the domain of strategy.
Second, we must ask which institutions fall under the control of the hand of government? By their nature, public formal institutions qualify. If such a formal institution changes, it must be an outcome of government intention to exert an influence upon business. The nature of formal institutions, being under governmental control, is that they may be changed relatively quickly, by executive or legislative action. While in many ways formal institutions reflect a sense of stability and permanence, part of their purpose is also to respond in a timely manner to new information and new situations. It is also their nature to be more extensive in geographic scope than informal institutions could hope to be, at least historically (North, 1991). Informal institutions rely upon socialization for their ability to control, and rely on social processes to change. This is necessarily a slow and uneven process, although undoubtedly social media already will have had an impact on this generalization. It is not at all impossible that governments might utilize social processes to effect official policy change through informal institutions. For JIBP, such a case might well be relevant, but its policy relevance must be argued convincingly.

In this regard, what exactly qualifies as policy was a concern in the paper by Buckley, Clegg, Cross, Liu, Voss, and Zheng et al. (2007) on the determinants of Chinese outward foreign direct investment. Deng Xiaoping's South China Tour in 1992 clearly had the effect of a policy change at the national level and was official, even though unwritten. This policy edict by the President of China was observed by the whole nation and employed what we could describe as an early form of a social mechanism to exhort business, in this case to internationalize. It had an extensive and deep suasive impact, giving impetus to the sum of policy innovations to date in China promoting internationalization (Buckley, Clegg, Voss, Cross, Liu, \& Zheng, 2018). The imprimatur of the president gave significance to existing legislation. In the paper, this liberalization was captured by a simple time dummy as, rare for policy changes, it was not trailed in advance and so the impact was clear cut. The relevance of this to this editorial is that it is something of an open question as to what exactly counts as policy, beyond the need at some point for the agency of a government and its formal institutions. As the field of international business policy is under development, all we ask is that authors problematize and justify their research in terms of international business policy, and present a well- 
argued case, supported with theoretical or empirical evidence, or both.

\section{POLICY AND ITS INTERACTION WITH THE FIRM}

In the example of Chinese outward foreign direct investment above, there are clear deficiencies. The paper argued that domestic liberalization, initiated by Deng Xiaoping's Southern Tour, led to enterprises' internationalization in line with national economic development policy. This internationalization was supported by subnational authorities actively promoting international business activities of enterprises under their supervision. However, there is no mechanism specified for how firms should react, nor which firms should react, and which ones not, and so on. A common device in quantitative research is to employ a time lag to simulate a decision-making process, but this hardly adds up to a theory-driven approach. As it happened, the effects of the Chinese policy were strong enough to punch through the model, but the value of this example is to highlight that a whole area is open for researchers to investigate exactly how policy is received and acted upon within firms in the general case, and whether there are differences across firm types.

The commonly quoted words of Douglass North that institutions are the "humanly devised constraints" or "the rules of the game in a society" (North, 1990: 3) are intuitively easy to understand. However, precisely how they exert their effect within the decision-making processes of firms is a matter of crucial importance to international business policy research. Again, we have to appreciate the need to scale up from the individual mind to the corporate mind, and the diffusion process from one corporate mind to another (DiMaggio \& Powell, 1983). The corporate "mind" may well differ between entrepreneurial firms, small and mediumsized enterprises, larger corporations, and multinational enterprises. The form of ownership may well also be an important consideration. Thus, the challenge to the researcher is to consider how all of these various forms of ownership and control including foreign ownership of domestic enterprises - may well influence responses to policy.

The language of institutional theory is couched in terms of restrictions - "constraints", "rules". This is less of a problem when it comes to compliance, or policies that constrain action, but it places the researcher in a quandary when investigating the intention by governments to promote international business. For example, governments employ incentives to encourage firms to internationalize. The language of "constraints" and "rules" no longer seems so appropriate in this context. Rather, we need to talk in terms of policy uptake, which is a function of awareness and an evaluation of the policy by the cohort of targeted firms. And to understand policy uptake, we really do need a more accurate model of decision making in the firm (Torres, Clegg \& Varum, 2016).

There is no theory of everything. The choice of theoretical engine in international business policy research needs to be presented and argued for. We have to choose, or develop, theories according to the research question being asked and its potential to better explain the class of observations in question. So it is with international business policy research. To scale up institutional theory from its action at the individual to the corporate level of decision making, studies have often drawn on the framework of Scott (2013), which identifies three types of institutions: regulative, normative, and cultural-cognitive. These are slices through the complete family of forces within institutional theory operating upon corporate behavior. These types owe their origin to distinct disciplines, for example, sociology, political science, and psychology (Dunning \& Lundan, 2008). The theoretical engine for addressing the chosen research question is likely to come from a cognate discipline. Thus, in the regulative domain, we should see a mapping all the way through from a government intention, through policy, to an action upon firms' behavior as a result of policy change. This action upon firms is likely to be complex. Compliance by corporations with policy affecting international business may well be modified by the responses of executives and managers in the normative and culturalcognitive domains. Thus, a more behavioral approach to the policy response is likely to be valuable in the future.

At the same time, international business policy does not, and cannot, simply materialize from within political circles alone. It is necessary to track back, to explore how international business policy comes into existence. This means that the antecedents of international business policy are relevant where they can be traced through to an effect on policy making and, ultimately, to a policy effect. Here I briefly consider how this might be done with regard to our theme of the relation between policy and institutions. The idea of 
institutional work (Lawrence \& Suddaby, 2006) concerns the action upon institutions and therefore may be a fruitful way of outlining the mechanism by which institutional change, i.e., policy, comes about.

The agency of firms means that they deploy and utilize resources to create new institutions or to modify existing institutions in a way that better meets their interests (DiMaggio, 1998). Taking institutional work as the "purposive action of individuals and organizations aimed at creating, maintaining and disrupting institutions" (Lawrence $\&$ Suddaby, 2006: 215) it is possible to envisage and design international business policy research questions that investigate the motives and processes of firms and other interest groups to engage in institutional work in the formal sphere. The literature on corporate political action (or business political action) deals with "any deliberate firm action intended to influence governmental policy or process." (Getz, 1997). For our present purpose, corporate political action (CPA) must then result in international business policy rather than wider goals, such as public relations. Getz (1997) distinguishes CPA from "political behavior", which she defines, following Boddewyn (1988: 342) as "particular ways of relating to targets located in the nonmarket environment of firms." Corporate political strategy is thus focused on gaining advantage for the firm vis-à-vis other firms, while CPA is directed towards a policy objective. The co-evolution of firms and institutions in an international business context (Cantwell, Dunning \& Lundan, 2010; McGaughey, Kumaraswamy, \& Liesch, 2016) is another good pointer to a future research agenda on policy formation. Taking this argument further could lead to an investigation of how international business policy is an outcome of the co-evolving relation between government - including international organizations - and business.

Rather than prescribe all the institutions that might exert international business policy impact, we must rather ask authors for a theoretical rationale. This leads to my next point, which is that international business policy should be designed into the research project from the outset. A research project may have other scientific objectives, for example, theory building and managerially-relevant analysis suitable to lead towards publication in the Journal of International Business Studies (JIBS). But for JIBP, there must be a clearly identified international business policy research question, and from that, conclusions relevant for the design and implementation of policy can be derived.

\section{INTERNATIONAL BUSINESS POLICY IN RETROSPECT AND PROSPECT}

The international business policy agenda was extensive in the 1960s and the 1970s and dealt with the big issues of the time, for two main reasons. The first was the concern in the advanced economies over the need for controls on outward FDI. Particularly in the USA and the UK it was felt that outward investment represented the exporting of employment, and had negative effects upon the domestic economy (Hood \& Young, 1979). A second reason was that the developing economies of the world were very concerned about economic colonization through inward investment. Dunning and Lundan (2008) review the body of work relevant to policy at the time of their writing. We can see that much international business policy research has been in the form of large-scale conceptual frameworks, especially of bargaining between states and MNEs, many in the line of descent from Vernon (1971) including the scoping out of the types of instruments at individual states' disposal and, at the larger scale, the multilateral approach that groups of states might adopt (for example, Grosse, 2005; Ramamurti, 2001). The tension this created was productive, and international business research was more integrated at this time with how the interests of firms and the development goals of governments could be reconciled (for example, Behrman, 1970).

The political changes that took place within economies - and between economies - in the 1980s towards market liberalization had the effect of taking the default stance of policy hostility towards inward FDI off the menu. Concern about home and host state control over investment flows was replaced by much more pragmatic concerns regarding the opening up of markets and deregulation to maximize the national share of global investment. While policy reversed its polarity (Buckley \& Clegg, 1991), academic international business research had already become preoccupied with theory and research into the mechanisms of international business at the firm level largely divorced from social questions (Van Assche, 2018).

These earlier "big-issue" approaches remain relevant for the guidance they offer as to where the action is in international business policy research in areas such as sustainability and the 
environment, international taxation, and ethics. To embed such policy concerns within the modern international business policy research agenda, we need theories that can be tested, and we need tests of these theories. In other words, we have to move to a scientific approach, to achieve both rigor and relevance to policy as it is actually implemented. Inspiration for academics can come from sources such as the United Nations Conference on Trade and Development (UNCTAD) and, in particular, its Division on Investment \& Enterprise (DIAE). UNCTAD has kept the lamp of international business policy research alight over the years with its publications, notably the World Investment Report (WIR). Today, the policy agenda is richer than ever before. A case in point is inward investment screening, handled by the 2018 WIR (UNCTAD, 2018). Many countries have investment screening regimes in place. A recent initiative of the European Union to bring about an EU-wide system of investment screening (European Commission, 2017,2018 ) has stimulated interest in the topic. The rise of direct investment by emerging economy multinationals and, in particular, those that are state backed, has made this concern especially salient to the advanced economies. Policymakers and public research program designers, such as those in the relevant directorates general in the European Commission, would be right to be disappointed by the poverty of recommendations that are so far on offer from academic researchers. Equally, the home countries of these new multinationals are justifiably concerned at what they see as discriminatory investment policies. In every respect, international business research is in the best possible position to rectify this situation, being in possession of the theoretical knowledge and the tools to contribute to policy.

\section{ORIGINALITY AND THE "DOUBLE HURDLE"}

In looking forward, international business policy researchers face a double hurdle. Research must be original and rigorous, and it must be relevant to policy. This has a direct impact on the reviewing of submissions to the Journal. The standard pool of JIBS researchers can be called on to ensure theoretical and empirical rigor. However, the burden is also upon the editorial team to find reviewers who are knowledgeable about the policy domain, even if these reviewers know no international business theory.
No one paper within international business policy research will single-handedly transform the state of our knowledge. Scientific research only advances through sustained effort by cohorts of researchers. Research is necessary in theory building and theory testing. At present, within international business policy research, we start with a deficit in theory. For this reason, phenomenonbased research - the great strength of international business as a field of study - promises to yield advances, not only for policy but also for theory.

There is another very good reason for focusing on the application of policy, as opposed to simply tracing institutional differences between countries. Everything that we observe within international business will be the outcome not only of private decision making but also of countless policies, too extensive to enumerate and impossible to evaluate in toto. Home-country policies, host-country policies, international treaties, and supranational organizations will all have played their part in generating the extant conditions. Therefore, isolating the effect of institutional differences in explaining the current state of the world with regard to international business, is an insuperable task. Investigating policy action, however, is feasible and likely to yield considerable returns in knowledge and scientific understanding. Researching international business policy requires theoretical innovation. Institutional differences can be instructive to international business policy researchers, but only when they are theorized. Thus, theory building has an important place in the research agenda, to explore alternative worlds, counterfactuals ("anti-mondes") and the proposed effects of changes. Given that policy research questions must be "designed in" ab initio and scientific rigor remains paramount, JIBP gives us all in the international business community the stimulus to tackle the big issues.

\section{CONCLUSION}

Institutions are not relevant to international business policy simply by virtue of shaping behavior. However, if they are amenable to government control or, more generally official control, and they have either (or both) a theoretical or empirical effect upon international business, then public action to change them falls within the scope of international business policy. By extension, it would be reasonable to argue that the antecedents 
of international business policy would be of interest. Firm agency that generates policy change and policy impact is an excellent example, be it by business or any other actor or constituency. The international business policy researcher must put forward the case for the disciplinary approach needed for the chosen research question, i.e., the relevant literature or literatures to review. If there is no policy dimension to the research - e.g., as with comparative institutional analysis - then any such study will fail the relevance-to-policy test. International business policy research has focused on firms' responses - typically cast as slavish responses - to comparative institutions, without investigating changes in these institutions instigated by government. The good news is that the field is wide open and, as IB researchers, we already have all the tools at our fingertips to investigate the policy dimension.

Thinking of institutions in terms of constraints or rules of the game draws our attention away from the fact that policy is also about action - yes, sanctions, but also promotion, in particular incentives to a particular course of action by firms. This means that in addition to awareness of the existence of policy, we must also model the uptake of the policy. To explain how firms respond generally, we need new approaches to firm decision making

\section{REFERENCES}

Behrman, J. N. 1970. National interests and the multinational enterprise. Englewood Cliffs, NJ: Prentice-Hall.

Boddewyn, J. J. 1988. Political aspects of MNE theory. Journal of International Business Studies, 19(3): 341-363.

Buckley, P. J., \& Clegg, L. J. (Eds.). 1991. Multinational enterprises in less developed countries. London: Macmillan.

Buckley, P. J., Clegg, L. J., Cross, A. R., Liu, X., Voss, H., \& Zheng, P. 2007. The determinants of Chinese outward foreign direct investment. Journal of International Business Studies, 38(4): 499-518.

Buckley, P. J., Clegg, L. J., Voss, H., Cross, A. R., Liu, X., \& Zheng, $P$. 2018. A retrospective and agenda for future research on Chinese outward foreign direct investment. Journal of International Business Studies, 49(1): 4-23.

Cantwell, J. A., Dunning, J. H., \& Lundan, S. M. 2010. An evolutionary approach to understanding international business activity: The co-evolution of MNEs and the institutional environment. Journal of International Business Studies, 41(4): 567-586.

DiMaggio, P. J. 1998. The new institutionalism: Avenues of collaboration. Journal of Institutional and Theoretical Economics, 154(4): 696-705.

DiMaggio, P. J., \& Powell, W. W. 1983. "The iron cage revisited": Institutional isomorphism and collective rationality in organizational fields. American Sociological Review, 48(2): 147-160.

Dunning, J. H., \& Lundan, S. M. 2008. Multinational enterprises and the global economy (2nd edn). Cheltenham: Edward Elgar. that better reflect reality. A firm-centric dimension is important to complete the modeling of international business policy.

The Journal of International Business Policy has a mission to publish research that meets the double hurdle of academic rigor and policy relevance. International business researchers need to combine - to interact - the familiar models of international business with policy questions. Building these policy research questions in at the start of research projects promises to address the frustration felt by many policy bodies outside academia. It follows that talking to policy bodies is essential. National and international organizations are more than willing to talk to academic researchers, to encourage us to go beyond mere analysis, to produce policy recommendations. To name but two, there are the institutions of the $\mathrm{EU}$ and the United Nations, in particular UNCTAD - which for many years has been an advocate of academics contributing to the policy domain. But there are many others. This dialogue promises to revitalize the field of international business and rejuvenate international business policy - essential if international business research is to help address the big challenges that the world faces.

Edgeworth, F. Y. 1881. Mathematical psychics: An essay on the application of mathematics to the moral sciences. London: C. Kegan Paul \& Co.

European Commission. 2017. Proposal for a regulation of the European Parliament and of the Council establishing a framework for screening of foreign direct investments into the European Union. Brussels, 13 September 2017. http://www.europarl. europa.eu/RegData/docs_autres_institutions/commission europeenne/com/2017/0487/COM_COM(2017)0487_EN̄. pdf.

European Commission. 2018. Commission welcomes agreement on foreign investment screening framework, Brussels, 20 November 2018. http://europa.eu/rapid/press-release_IP-186467_en.htm

Getz, K. A. 1997. Research in corporate political action: Integration and assessment. Business \& Society, 36(1): 32-72.

Grosse, R. (Ed.). 2005. International business and government relations in the 21st century. Cambridge: Cambridge University Press.

Hood, N, \& Young, S. 1979. The economics of multinational enterprise. London \& New York: Longman.

Lawrence, T. B., \& Suddaby, R. 2006. Institutions and institutional work. In S. C. Clegg, C. Hardy, T. B. Lawrence, W. R. Nord (Eds), Handbook of organizational studies, 2nd edn: 215254. London: Sage.

Lundan, S. M. 2018. From the editor: Engaging international business scholars with public policy issues. Journal of International Business Policy, 1(1-2): 1-11. 
McGaughey, S. L., Kumaraswamy, A., \& Liesch, P. W. 2016. Institutions, entrepreneurship and co-evolution in international business. Journal of World Business, 51(6): 871-881.

North, D. C. 1990. Institutions, institutional change and economic performance. Cambridge: Cambridge University Press.

North, D. C. 1991. Institutions. Journal of Economic Perspectives, 5(1): 97-112.

Oxford English Dictionary. 2004. (11th Edn). Oxford: Oxford University Press.

Ramamurti, R. 2001. The obsolescing 'bargaining model?' MNC-host developing country relations revisited. Journal of International Business Studies, 32(1): 23-39.

Scott, W. R. 2013. Institutions and organizations: Ideas, interests, and identities (4th edn). London: Sage.

Torres, M. M., Clegg, L. J., \& Varum, C. A. 2016. The missing link between awareness and use in the uptake of prointernationalization. International Business Review, 25(2): 495-510.

UNCTAD. 2018. World Investment Report 2018: Investment and new industrial policies. New York and Geneva: UNCTAD.

Van Assche, A. 2018. Steering a policy turn in international business - opportunities and challenges. Journal of International Business Policy, 1(3-4): 117-127.
Vernon, R. 1971. Sovereignty at bay: The multinational spread of U. S. enterprises. New York: Basic Books.

\section{ABOUT THE AUTHOR}

Jeremy Clegg is Jean Monnet Professor of European Integration \& International Business Management at the University of Leeds, United Kingdom, and an area editor of the Journal of International Business Policy. His research, employing both quantitative and qualitative methods, encompasses the determinants of foreign direct investment, FDI and regional integration, outward FDI by emerging economies, and also human factors within international business.

Publisher's Note Springer Nature remains neutral with regard to jurisdictional claims in published maps and institutional affiliations. 